\title{
Quality of life of institutionalized aged with and without symptoms of depression
}

\author{
Qualidade de vida de idosos institucionalizados com e sem sinais de depressão \\ Calidad de vida de los ancianos institucionalizados con y sin síntomas de depresión
}

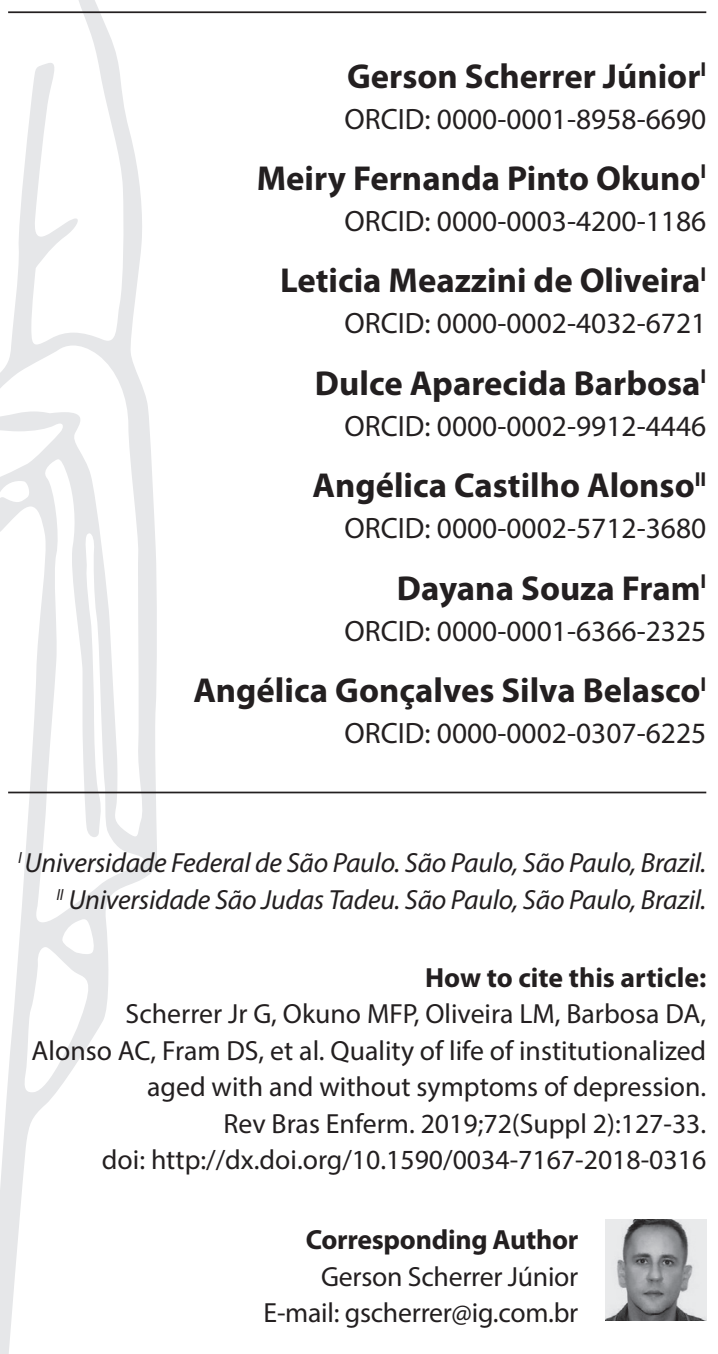

Submission: 05-16-2018
Approval: 08-09-2018

\section{ABSTRACT}

Objective: compare the quality of life (QOL) of aged residents in homes for aged people with or without symptoms of depression, and identify social, physical activity leisure; health and basic activities of daily living (ADL) variables that correlate with QOL scores. Method: cross-sectional study conducted with 101 institutionalized aged. Multiple linear regression was used for data analysis. Results: symptoms of depression changed negatively the QOL in the domains: autonomy; present, past and future activities; social participation; intimacy and total score. Dependent aged presented lower QOL for the performance of ADL in the domains: autonomy; social participation and total score; dancing without limitation of movement; liking the residential and not presenting symptoms of depression were the variables that positively influenced the QOL of the aged. Conclusion: social and psychological support, good living conditions and stimulating assistance can improve the QOL of institutionalized elderlies. Descriptors: Homes for the Aged; Quality of Life; Depression; Activities of Daily Living; Aged.

\section{RESUMO}

Objetivo: comparar a qualidade de vida (QV) de idosos residentes em instituições de longa permanência com ou sem sinais de depressão, e identificar variáveis sociais, de atividade física, lazer, saúde e atividades básicas da vida diária (ABVD) que se correlacionam aos escores de QV. Método: estudo transversal realizado com 101 idosos institucionalizados. A regressão linear múltipla foi usada para a análise dos dados. Resultados: sinais de depressão alteraram negativamente a QV nos domínios: autonomia, atividades presentes, passadas e futuras, participação social, intimidade e escore total; idosos dependentes para a realização das $\mathrm{ABVD}$ apresentaram $\mathrm{QV}$ inferior nos domínios: autonomia, participação social e escore total; dançar sem limitação de movimento, gostar do residencial e não apresentar sinais de depressão foram as variáveis que influenciaram positivamente a QV dos idosos. Conclusão: suporte social e psicológico, boas condições de moradia e assistência estimuladora podem melhorar a QV de idosos institucionalizados.

Descritores: Instituição de Longa Permanência para Idosos; Qualidade de Vida; Depressão; Atividades Cotidianas; Idoso.

\section{RESUMEN}

Objetivo: comparar la calidad de vida (CV) de los ancianos residentes en instituciones de larga permanencia con o sin síntomas de depresión, e identificar variables sociales, de actividad física, de ocio, de salud y de actividades básicas de la vida diaria (ABVD) que se correlacionan con las puntuaciones de CV. Método: estudio transversal realizado con 101 ancianos institucionalizados. Para el análisis de los datos se utilizóla regresión lineal múltiple. Resultados: los síntomas de depresión cambiaron negativamente la CV en los dominios: autonomía; actividades presentes, pasadas y futuras; participación social; intimidad y puntuación total. Los ancianos dependientes para la realización de la ABVD tuvieron menor CV en los dominios: autonomía, participación social y puntuación total; bailar sin limitación de movimiento, gustar de lo hogar, y no mostrar síntomas de depresión, fueron las variables que influenciaron de forma positiva en la CV de los ancianos. Conclusión: el apoyo social y psicológico, unas buenas condiciones de vida y una asistencia estimulante pueden mejorar la calidad de vida de los ancianos institucionalizados.

Descriptores: Hogares para Ancianos; Calidad de Vida; Depresión; Actividades Cotidianas; Anciano. 


\section{INTRODUCTION}

Since the mid-twentieth century, population aging in developed countries has been significant, and this phenomenon is currently beginning to have an impact on developing countries ${ }^{(1-2)}$. Decreasing fertility and increasing longevity boost global ageing, changing the demographic and epidemiological pattern ${ }^{(3)}$. From 2005 to 2015, the proportion of aged people in Brazil of 60 years and older went from $9.8 \%$ to $14.3 \%{ }^{(4)}$.

According to the Brazilian Institute of Geography and Statistics (IBGE), life expectancy at birth in 2010 was 73.48 years and in 2014, it reached 75.14 years $^{(5)}$. Population aging increases the prevalence of chronic diseases, fragilities and functional disabilities that require specialized care, readjustment of health services and increased search for homes for aged (HFA) ${ }^{(6)}$.

HFA is a residential social service facility, where a collective of people aged 60 and over lives in conditions of freedom, dignity and citizenship ${ }^{(7)}$. Institutionalization tends to accelerate the dependence for the performance of basic activities of daily living $(A D L)^{(8)}$, which are an indicator of the functional capacity of the aged in the physical and social environment ${ }^{(9)}$. Functional disability interferes in the quality of life (QOL), as it is the inability or difficulty to perform tasks that are part of the daily life of the aged person and that are usually indispensable for an independent life in the community ${ }^{(10)}$.

$\mathrm{QOL}$ is seen in a comprehensive context and can be affected by both physical/ mental health and the level of functional independence, in addition to bringing consequences for social relationships, personal beliefs and relationships with the environment ${ }^{(9)}$.

A significant social and health challenge in HFA is the high prevalence of depression, pointing to functional limitation as the main cause worldwide ${ }^{(11)}$. The literature reports a variation from $48 \%$ to $60 \%$ of depression among institutionalized aged people and indicates other causes for the presence of depressive symptoms, such as the fact that they live alone, are widows and are institutionalized $^{(12)}$.

Depression is a disorder of the emotional area or mood, characterized by strong physical and mental impact. Its multifactorial nature involves numerous aspects of a biological, psychological and social nature ${ }^{(13)}$.

The most relevant clinical manifestation in the aged with depression is late onset, often associated with cognitive disorders and worse performance in neuropsychological tests. It can be related to negative life events, social problems, presence of physical diseases, disabilities, increased risk of developing the disease and damage for $\mathrm{QOL}^{(14)}$.

In addition to investigating and determining the rate of ageing of the population, it is necessary to assess the quality of ageing. QOL in old age is associated with the perception of the experience that each individual has and involves several biological, psychological and socio-structural criteria; as well as cultural aspects, values, goals, expectations and concerns of the elderly in relation to life ${ }^{(15)}$.

The institutionalized elders need social and health support, have functional and social disabilities, depression and low QOL. This new profile of the Brazilian population motivated this study, which was based on the following guiding question: what is the quality of life of elders living in homes for aged?

\section{OBJECTIVE}

Compare the QOL of elderly residents in HFA with or without symptoms of depression and identify social, physical activity, leisure, health and ADL variables that correlate with QOL scores.

\section{METHOD}

\section{Ethical aspects}

This study was preceded by the approval of the Ethics Committee, authorization of the HFA and with the informed consent form of the participants of the study. Everyone was informed about the guarantee of confidentiality of the information, absence of any kind of costs and the right to give up the research at any time if they wanted. Respecting the Resolution of the National Health Council no. 466, of December 12, 2012.

\section{Design, place of study and period}

This is a cross-sectional and analytical study conducted in four private and high economic standard HFA in São Paulo, with an average monthly fee of 15 minimum wages. The conditions offered by the HFA were similar in relation to the complexity of assistance, services, infrastructure, weekly programming of activities that stimulate the mind and body, gastronomic options and qualified multiprofessional team. Data collection occurred from January 2014 to February 2015.

\section{Population and sample; inclusion and exclusion criteria}

The population of the four HFA was 650 aged people, of whom $549(84.46 \%)$ did not participate in the study. Thus, the sample consisted of 101 (15.54\%) residents. The sample included the elders of both genders, age $\geq 60$ years, residents for at least three months and who presented favorable conditions for understanding the questionnaires, according to the Mini Mental Condition Examination (MMCE) of 19 points or more for literate ${ }^{(12)}$. The elders who did not agree to participate in the study, who had lowered their level of consciousness, impaired cognition, and who did not speak or understand the Portuguese language were excluded.

\section{Study protocol}

Data collection was done by individual interview, in a private environment, at the HFA. The first instrument applied was the MMCE, evaluating cognition and guided the continuity of the others. Elders who had a lower score according to the level schooling, 19 points for illiterate people, 23 points for elders with one to three years of schooling, 24 points for elders with four to seven years of schooling and 28 points for those above seven years of schooling. The social, cultural, physical activity, leisure and disease information was collected by a questionnaire prepared by the authors of the study, including the variable: social (age, gender, marital status and skin color), cultural (schooling level and religion), physical activity, leisure and disease. Signs and symptoms of depression by the Beck Depression Inventory (BDI), QOL by the World Health Organization Quality of Life Group (WHOQOL-OLD) and ADL by the Katz Index. 
To assess the presence or absence of signs and symptoms of depression, Beck Depression Inventory (BDI) was used, consisting of 21 questions, with four alternatives that describe traits that characterize or not signs and symptoms of depression. Responses range from 0 (absence of signs and symptoms) to 3 (more pronounced signs and symptoms of depression) and a total score above 10 points is classified as depression ${ }^{(13)}$. QOL was evaluated by WHOQOL-OLD, composed of 24 questions and six domains. The first evaluates the sensory functioning and the impact of the loss of sensory skills on the activities of daily living and the ability to interact with other people in the quality of life of the aged. The second is autonomy, which refers to independence in old age, describing the extent to which the elders are able to live independently and make their own decisions. Third, past, present and future activities, describing the satisfaction about achievements in life, projects and future aspirations. The fourth domain is social participation, referring to the participation in daily activities, especially in the community in which the elders are inserted. In fifth place is death and dying, related to concerns, worries, expectations and fears about death and dying. The sixth place is intimacy, assessing the ability to have personal and intimate relationships. Each question has answers ranging from one to five points, and each domain has its own score. The total score ranges from 24 (worst state) to 100 (best state) ${ }^{(14)}$. The ADL were evaluated according to the Katz index, which determines the ability to take care of oneself and to perform daily activities, based on a scale of six activities that the elders inform if they can do, with one point, or not, with zero. In the final score, the lower the score indicates the higher dependence for the performance of the $\mathrm{ADL}^{(15)}$.

\section{Analysis of results and statistics}

A descriptive analysis of continuous variables was performed to compare the QOL of patients with and without signs and symptoms of depression by the analysis of variance (ANOVA), and the general linear model was used to compare the QOL, BDI and ADL domains.

The multiple linear regression analysis showed which variables best explained the QOL scores and their selection was made by the Stepwise method, considering a significance level of $5 \%$.

\section{RESULTS}

We evaluated 101 elders with an average age of 85.4 (ranging from 63 to 108) years; average number of diseases of 5.9 (ranging from 0 to 14); drugs taken daily on average 8.2 (ranging from 0 to 16); average number of sons 2.0 (ranging from 0 to 7); average time of institutionalization of 3.8 (ranging from 1 to 13) years; average income of 15 minimum wages per aged person. $75.2 \%$ of them were independent; $11.9 \%$ partially dependent; $12.9 \%$ totally dependent to perform ADL; $52.5 \%$ presented signs and symptoms of depression, $36.6 \%$ of these with signs and symptoms of mild depression, $11.9 \%$ moderate and $4 \%$ severe.

Table 1 presents the sociodemographic, cultural, economic, presence of pain, physical and leisure activities characteristics of the elders included in the study. The predominant female gender was composed of widows, white, catholic, with a high level of education, maintained by public welfare, who practiced physical activity, leisure and who presented some kind of pain.
Table 2 shows that the elders with signs and symptoms of depression present QOL scores significantly worse in the domains of autonomy; past, present and future activities; social participation; intimacy and total score, than the elders without signs and symptoms of depression.

Table 1 - Sociodemographic, cultural, economic, presence of pain, physical activity and leisure characteristics of aged people living in high standard institutions, São Paulo, Brazil, January 2014 to February 2015

\begin{tabular}{|c|c|}
\hline Characteristics & Frequency (\%) \\
\hline \multicolumn{2}{|l|}{ Gender } \\
\hline Female & $82(81.2)$ \\
\hline Male & $19(18.8)$ \\
\hline \multicolumn{2}{|l|}{ Marital status } \\
\hline Widow & $67(66.3)$ \\
\hline Single & 15 (14.9) \\
\hline Married & 12 (11.9) \\
\hline Divorced or separated & $7(6.9)$ \\
\hline \multicolumn{2}{|l|}{ Skin color } \\
\hline White & $98(97.0)$ \\
\hline Not white & $3(3.0)$ \\
\hline \multicolumn{2}{|l|}{ Religion } \\
\hline Catholic & $74(73.2)$ \\
\hline Other & $22(21.8)$ \\
\hline Evangelical & $3(3.0)$ \\
\hline Spiritism & $2(2.0)$ \\
\hline \multicolumn{2}{|l|}{ Level of education } \\
\hline Elementary incomplete & $18(17.8)$ \\
\hline Elementary complete & $11(10.9)$ \\
\hline High & $31(30.7)$ \\
\hline College complete & $41(40.6)$ \\
\hline \multicolumn{2}{|l|}{ Financial Resource } \\
\hline Rental property & $26(25.7)$ \\
\hline \multicolumn{2}{|l|}{ Retirement } \\
\hline Public pension & $62(61.4)$ \\
\hline Private pension & $6(5.9)$ \\
\hline Application & 37 (36.6) \\
\hline Sons cover the cost & $23(22.8)$ \\
\hline Pension & $22(21.8)$ \\
\hline \multicolumn{2}{|l|}{ Physical activity } \\
\hline Yes & $61(60.4)$ \\
\hline No & 40 (39.6) \\
\hline \multicolumn{2}{|l|}{ Leisure activity } \\
\hline Yes & $86(85.1)$ \\
\hline No & $15(14.9)$ \\
\hline \multicolumn{2}{|l|}{ Presence of pain } \\
\hline Yes & $54(53.5)$ \\
\hline No & $47(46.5)$ \\
\hline
\end{tabular}

Table 2 - Quality of life scores, according to WHOQOL-OLD, of aged people living in high standard long-term institutions, with and without signs and symptoms of depression, measured by Beck depression inventory, São Paulo, Brazil, January 2014 to February 2015

\begin{tabular}{lccc}
\hline WHOQOL-OLD & $\begin{array}{c}\text { Without signs } \\
\text { and symptoms } \\
\mathbf{n = 4 8}(\mathbf{s d})\end{array}$ & $\begin{array}{c}\text { With signs } \\
\text { and symptoms } \\
\mathbf{n = 5 3}(\mathbf{s d})\end{array}$ & $\boldsymbol{p}$ value \\
\hline SF & $75.91(24.36)$ & $77.36(21.87)$ & 0.754 \\
AUT & $68.62(17.98)$ & $54.6(19.07)$ & $<\mathbf{0 . 0 0 1 *}$ \\
PPF & $70.31(18.16)$ & $58.61(19.96)$ & $0.003^{*}$ \\
SP & $66.93(19.64)$ & $59.08(19.71)$ & $0.048^{*}$ \\
DAD & $82.03(20.65)$ & $75.35(20.71)$ & 0.108 \\
INT & $65.36(24.05)$ & $53.18(26.65)$ & $0.018^{*}$ \\
Total score & $71.53(12.15)$ & $63.03(11.79)$ & $0.001^{*}$ \\
\hline
\end{tabular}

Note: ANOVA test; $s d=$ standard deviation; ${ }^{*} p=$ significant; $S F=$ sensory function; $A U T=$ auton omy; $P P F=$ past , present and future activities; $S P=$ social participation; $D A D=$ death and dying; INT = intimacy. 
Table 3 compares the level of dependence for performing ADL in three factors with the WHOQOL-OLD dimension scores. Autonomy, social participation and total score were significantly lower among the elders who were totally dependent for the execution of the ADL in relation to the independent elders.

Table 4 shows a comparative analysis of QOL scores according to the WHOQOL-OLD with two factors: presence or absence of signs and symptoms of depression, evaluated by Beck depression inventory; and the condition of development of ADL, classified by the Katz index and the interaction between depression and ADL.

It is possible to observe significance between the ADL factor with the domains of autonomy QOL ( $p$-value $=0.01$ ), social participation ( $p$-value $<0.01$ ) and total score ( $p$-value $=0.02$ ). When the interaction was analyzed, it showed significance for the totally dependent elders in relation to the independent elders for the domains autonomy ( $p$-value $<0.01$ ), social participation ( $p$-value $<0.01$ ) and total score ( $p$-value $=0.02$ ), regardless of having or not signs and symptoms of depression, which, according to the $p$-value of interaction, separates the depression groups and presents no statistical difference.

Table 5 shows the results of simple linear regression analysis and multiple linear regression of the variables that interfered in the QOL scores of institutionalized elders.

The analysis model identified that dancing, not having movement limitations, liking the household where they live and not showing signs and symptoms of depression were the variables that responded to the positive change in the quality of life of the elders in this study.

Table 3 - Comparison of the quality of life, according to the WHOQOL-OLD, of aged people living in high standard institutions, with the level of capacity to perform basic daily life activities according to the Katz index, São Paulo, Brazil, January 2014 to February 2015

\begin{tabular}{lcccc}
\hline WHOQOL-OLD & $\begin{array}{c}\text { Totally } \\
\text { Dependent }\end{array}$ & $\begin{array}{c}\text { Partially } \\
\text { Dependent }\end{array}$ & Independent & $\boldsymbol{p}$ value \\
\hline SF & $72.12(26.22)$ & $72.92(32.35)$ & $78.04(20.8)$ & 0.581 \\
AUT & $47.12(14.12)^{\mathrm{a}}$ & $54.69(23.25)$ & $64.72(18.87)^{\mathrm{a}}$ & $0.005^{*}$ \\
PPF & $58.65(25.2)$ & $59.38(21.73)$ & $65.87(18.61)$ & 0.328 \\
SP & $46.15(17.78)^{\mathrm{a}}$ & $57.29(17.64)$ & $66.53(19.19)^{\mathrm{a}}$ & $0.001^{*}$ \\
DAD & $83.17(15.39)$ & $85.42(16.06)$ & $76.64(22.11)$ & 0.279 \\
INT & $46.63(29.27)$ & $53.13(26.72)$ & $62.01(24.93)$ & 0.102 \\
Total score & $58.97(11.05)^{\mathrm{a}}$ & $63.80(13.39)$ & $68.97(12.27)^{\mathrm{a}}$ & $0.018^{*}$ \\
\hline
\end{tabular}

Note: ANOVA test; post hoc Bonferroni; $a=$ totally dependent versus independent; ${ }^{*} p=$ significant; $S F=$ sensory function; $A U T=$ autonomy; $P P F=$ past, present and future activities; $S P=s 0$ cial participation; $D A D=$ death and dying; INT = intimacy.

Table 4 - Average scores of WHOQOL-OLD domains according to the presence or not of signs and symptoms of depression and the classification of the level of dependence to develop the activities of daily living of aged people living in homes for aged, São Paulo, Brazil, January 2014 to February 2015

\begin{tabular}{lcccccc}
\hline & \multicolumn{3}{c}{ With symptoms } & \multicolumn{3}{c}{ Without signs and } \\
& TD & PD & I & TD & PD & I \\
& & & & & & \\
& & & & & & \\
SF & 70.8 & 78.9 & 78.6 & 75.0 & 60.9 & 77.5 \\
AUT & $44.4^{\mathrm{a}}$ & 53.1 & $57.5^{\mathrm{a}}$ & $53.1^{\mathrm{a}}$ & 57.8 & $71.2^{\mathrm{a}}$ \\
PPF & 58.3 & 54.7 & 59.5 & 59.4 & 68.7 & 71.6 \\
SP & $45.8^{\mathrm{a}}$ & 61.7 & $61.8^{\mathrm{a}}$ & $46.9^{\mathrm{a}}$ & 48.4 & $70.9^{\mathrm{a}}$ \\
DAD & 79.2 & 88.3 & 71.5 & 92.2 & 79.7 & 81.2 \\
INT & 52.1 & 47.6 & 54.7 & 34.4 & 64.1 & 68.6 \\
Total score & $58.4^{\mathrm{a}}$ & 64.1 & $63.9^{\mathrm{a}}$ & $60.2^{\mathrm{a}}$ & 63.3 & $73.5^{\mathrm{a}}$ \\
\hline
\end{tabular}

Note: general linear model; post hoc Bonferroni; $a=$ totally dependent versus independent cor respond to ${ }^{*} p$-value $\leq 0.02 ; T D=$ totally dependent; $P D=$ partially dependent; $I=$ independent; $S F=$ sensory function; $A U T=$ autonomy; $P P F=$ past, present and future activities; $S P=$ social participation; $D A D=$ death and dying; INT = intimacy.
Table 5 - Simple and multiple linear regression of the WHOQOL-OLD total score with variables related to leisure, physical activity, social, health, activities of daily living and signs and symptoms of depression in aged people residents of high standard institutions, São Paulo, Brazil, January 2014 to February 2015

\begin{tabular}{|c|c|c|c|c|}
\hline & $\begin{array}{l}\text { Simple re } \\
\text { Estimated }\end{array}$ & $\begin{array}{l}\text { gression } \\
\text { p value }\end{array}$ & $\begin{array}{l}\text { Multiple reg } \\
\text { Estimated }\end{array}$ & $\begin{array}{c}\text { gression } \\
p \text { value }\end{array}$ \\
\hline Dance & 15.04 & 0.019 & 11.09 & 0.040 \\
\hline Do gymnastics & 5.76 & 0.028 & - & - \\
\hline Leisure activity & 9.12 & 0.009 & - & - \\
\hline Watch TV & 6.01 & 0.019 & - & - \\
\hline Limitation of movements & -11.65 & $<0.001$ & -10.22 & $<0.001$ \\
\hline Loss of health & -7.59 & 0.002 & - & - \\
\hline Sick partner & 8.79 & 0.029 & - & - \\
\hline Like the residential & 10.98 & 0.026 & 8.85 & 0.033 \\
\hline Living alone & -8.96 & 0.007 & - & - \\
\hline Quantity of drugs & -0.86 & 0.010 & - & - \\
\hline Signs and symptoms depression & 8.5 & 0.001 & 6.71 & 0.002 \\
\hline Katz Index (ADL)* & -7.68 & 0.008 & - & - \\
\hline
\end{tabular}

Note: *: Activities of Daily Living.

\section{DISCUSSION}

In the literature review carried out for this research, we did not find studies with elders residing in high standard institutions in Brazil. It can be explained by the fact that $65.2 \%$ of the Brazilian institutions are philanthropic and do not maintain the same standard as the institutions analyzed, which made it difficult to compare the findings of this study ${ }^{(16)}$.

The elderly in this study had an average age of 85.5 years, exceeding the national projection of 75.1 years of $2014^{(5)}$. Female aged women, white, Catholic, widowed and with a median number of two sons were predominant, consistent with the characteristics of the aging Brazilian population ${ }^{(4)}$; and to be aged, white, widowed, and from a family with a smaller composition is something similar to the world's characteristics of the aged population ${ }^{(17)}$.

The findings related to the prevalence of older people with higher education level were different from two Spanish studies also in private institutions in Soria city ${ }^{(18)}$ and in the district of Abadengo in Salamanca ${ }^{(19)}$. The income of the elderly in this study is considered high, equal to or higher than 15 minimum wages, which differs from the study conducted in the coast of Rio Grande do Sul, with the predominantly illiterate elderly and with monthly income between one and two minimum wages ${ }^{(12)}$. Public retirement followed by financial investments were the main sources of income, findings consistent with studies conducted in the southeastern and southern regions of Brazil(20-21) and contrary to those of the northeastern region, whose incomes came from craft activities in $68.8 \%$ and retirement in $12.5 \%{ }^{(22)}$.

The chronological age is a triggering factor for the development of disabilities, and every ten years this risk doubles ${ }^{(22)}$. In this study, it does not converge, because although the average age is higher (85.5 years) than the national one, the independence to perform the ADL prevailed. Perhaps the protective effect for this aged population is high schooling, good socioeconomic condition, educational and cultural status, that keeps the body and mind active until more advanced ages ${ }^{(20)}$, associated with the lower risk of functional disability ${ }^{(23)}$. In two HFA in Itaúnas, Espírito Santo, only $23 \%$ of the elders were independent ${ }^{(24)}$. 
More than half of the participants in this study practiced some physical activity. Physical performance decreased considerably with aging; however, physical activity decreased functional decline. In particular, aerobic and endurance activities showed greater positive impact on physical performance. This observation reinforces the evidence that regular exercise is effective in improving the quality of life of the aged people ${ }^{(25)}$.

Watching television and reading were the leisure activities most commonly practiced by the elders studied. A study carried out in Florianópolis found that the main leisure habits are performed at home, such as watching television (95.7\%), sleeping (52.2\%), receiving visits and talking (52.2\%). It also showed that leisure activities promote social bonds, personal and intimate relationships, improving autonomy and quality of life in general(26).

With aging come changes in the ability of the subject to maintain skills, physical and mental abilities to live independently and autonomously. Aged people with some degree of dependence for $A D L$, in this study, presented QOL scores lower than the independent ones, with the exception of the death and dying domain whose score was higher in the dependent elders and significant in the domains autonomy, social participation and total score. The preservation of mental and physical function contributes to higher autonomy and functional independence, reflecting in the improvement of QOL and in the best emotional condition during the aging process ${ }^{(23)}$.

In this study, $52.5 \%$ of the elders presented signs and symptoms of depression, similar to two national surveys, one in Rio Grande do Sul(12), where 55\% of the elders residing in private institutions presented depression, and another in the Brazilian Northeast, precisely in Maceió, capital of Alagoas ${ }^{(27)}$, where $58 \%$ of institutionalized elders presented depression. In Spain, in Salamanca city ${ }^{(19)}$ the prevalence was $67.7 \%$. Depression is a health hazard that deserves attention in long-term institutions, due to its significant prevalence. Early diagnosis and treatment of signs and symptoms of depression contribute to the improvement of QOL in institutionalized aged people ${ }^{(28)}$.

Elders living in HFA show a greater impairment of QOL and cognitive and emotional states when compared to those living with the family. Although HFA may have a confinement character and lead to the lowest social stimulation of the subject, sometimes they become the only viable alternative to preserve survival mechanisms in the face of socioeconomic, affective and family difficulties encountered in the lives of the aged people ${ }^{(29)}$.

Aged people with signs and symptoms of depression, in general, presents a total QOL score lower than the groups without the same manifestations, however, in isolation, the domains sensory functioning and death and dying do not seem to be affected significantly from the signs and symptoms of depression. A study conducted in Taiwan indicates that the absence of signs and symptoms of depression significantly interferes in QOL of institutionalized aged people ${ }^{(30)}$.
According to the multiple linear regression analysis performed in this study, the variables that most positively interfered in the QOL scores were: dancing and liking the residential where they live and, negatively, having movement limitations and presenting signs and symptoms of depression. Aged people who had the habit of dancing, independence to perform the ADL, who liked the residential, and who did not present signs and symptoms of depression presented QOL significantly better than the others, in line with national and international studies ${ }^{(19-28)}$. In Hong Kong, pain, age less than 74 years, having sons, and cognitive impairment were factors that negatively interfered with QOL scores ${ }^{(31)}$.

In this study, no significant difference was found between the capacity to perform ADL and signs and symptoms of depression, perhaps due to the low prevalence of dependent elderly, which differs from most studies on functional capacity in the aged people ${ }^{(11,14,22)}$.

\section{Study limitations}

As for the development of this study, it is perceived as a limiting factor that it was conducted in long-term institutions for the aged, private, high standard and in São Paulo city, not representing other realities of the country. Also the difficulty of access to more institutions of the same standard, in order to expand the sample.

\section{Contributions to nursing, health or public policies}

Thus, the results found make it possible to identify the factors that interfere in QOL and the domains that are impaired, supporting more assertive health care interventions and improvement of QOL in the different segments of the aged. Besides contributing with scientific evidence for good practices with other residents of HFA, adapting them to different profiles.

\section{CONCLUSION}

The QOL of the aged with signs and symptoms of depression presented lower and statistically significant scores in the following domains: autonomy; present, past and future activities; social participation; intimacy and total score.

The QOL of the aged people who presented restrictions for the performance of ADL was significantly lower in the domains: autonomy, social participation and total score.

The habit of dancing, preservation of movements, liking the residential, and not showing signs and symptoms of depression were the variables that best influenced positively and significantly the QOL of the elders.

Thus, we concluded that the promotion of a stimulating environment, with varied activities, collective and appropriate to the sociocultural profile, provides preservation of physical and mental capacity decreases the prevalence of signs and symptoms of depression and enhances the QOL.

\section{REFERENCES}

1. United Nations. Department of Economic and Social Affairs. World population ageing 2013 [Internet]. New York: United Nations; 2013 [cited 2018 Apr 2]. Available from: http://www.un.org/en/development/desa/population/publications/pdf/ageing/WorldPopulationAgeing2013.pdf 
2. Instituto Brasileiro de Geografia e Estatística-IBGE. Censo demográfico 2010. Rio de Janeiro: IBGE; 2012.

3. Suzman R, Beard JR, Boerma T, Chatterji S. Health in an ageing world: what do we know? Lancet. 2015;385(9967):484-6. doi: 10.1016/ S0140-6736(14)61597-X

4. Instituto Brasileiro de Geografia e Estatística-IBGE. Síntese de indicadores sociais (SIS): uma análise das condições de vida da população brasileira 2016 [Internet]. Rio de Janeiro: IBGE; 2016 [cited 2018 Apr 2]. Available from: https://www.biblioteca.ibge.gov.br/visualizacao/ livros/liv98965.pdf

5. Instituto Brasileiro de Geografia e Estatística-IBGE. Esperanças de vida ao nascer. Rio de Janeiro: IBGE; 2014.

6. Sánchez-Pérez I, Garcia NC, Piniella LR, Martos GP, Bataller GA, Coderch J. [Hospital emergencies arising from nursing homes in a region: evolution, characteristics and appropriateness]. Gac Sanit [Internet]. 2018 [cited 2018 Apr 10];32(1):27-34. Available from: http://scielo.isciii. es/pdf/gs/v32n1/0213-9111-gs-32-01-00027.pdf Spanish.

7. Toribio-Ferrer C, Franco-Barcenas S. [Perception of older adults about their experiences in a nursing home]. Rev Enferm Inst Mex Seguro Soc [Internet]. 2018 [cited 2018 Apr 10];26(1):16-22. Available from: http://revistaenfermeria.imss.gob.mx/editorial/index.php/revista_ enfermeria/article/view/293/709 Spanish.

8. Pagotto V, Silva VAP, Pereira LV, Santos DPMA. Functionality comparison of elderly residing in two institutional modalities. Rev Eletr Enferm [Internet]. 2016 [cited 2018 Apr 2];18:e1143. Available from: https://revistas.ufg.br/fen/article/view/34712/21177

9. Ribeiro LHM, Neri AL. Physical exercise, muscle strength and the day-to-day activities of elderly women. Ciênc Saúde Colet. 2012;17(8):216980. doi: 10.1590/S1413-81232012000800027

10. Barbosa BR, Almeida JM, Barbosa MR, Rossi-Barbosa LAR. Evaluation of the functional capacity of the elderly and factors associated with disability. Ciênc Saúde Colet. 2014;19(8):3317-25. doi: 10.1590/1413-81232014198.06322013

11. Leal MCC, Apóstolo JLA, Mendes AMOC, Marques APO. Prevalence of depressive symptoms and associated factors among institutionalized elderly. Acta Paul Enferm [Internet]. 2014 [cited 2017 Apr 2];27(3):208-14. Available from: http://www.scielo.br/pdf/ape/v27n3/en_19820194-ape-027-003-0208.pdf

12. Güths JFS, Jacob MHVM, Santos AMPV, Arossi GA, Béria JU. [Sociodemographic profile, family aspects, perception of health, functional capacity and depression in institutionalized elderly persons from the north coastal region of Rio Grande do Sul, Brazil]. Rev Bras Geriatr Gerontol [Internet]. 2017 [cited 2018 Apr 3];20(2):175-85. Available from: http://www.scielo.br/pdf/rbgg/v20n2/pt_1809-9823rbgg-20-02-00175.pdf Portuguese.

13. Verçosa VSL, Cavalcanti SL, Freitas DA. Prevalence of depressive symptomology in institutionalized elderly people. Rev Enferm UFPE[Internet]. 2016 [cited 2018 Apr 2];10(5):4264-70. Available from: https://periodicos.ufpe.br/revistas/revistaenfermagem/article/ view/11172/12707

14. Rossetto M, Maia KS, Silva VC, Pinto EC, Cosentino SF, Soler MG. [Depression in elders of a long stay institution]. Rev Enferm UFSM [Internet]. 2012 [cited 2018 Apr 4];2(2):347-52. Available from: https://periodicos.ufsm.br/reufsm/article/view/4599/3759 Portuguese.

15. Bassler TC, Santos FR, Santos Jr AG, Furlan MCR, Maia CR. Quality of life evaluation of the elderly living in a for long stay care institution. Rev Enferm UFPE[Internet]. 2017 [cited 2018 Apr 2];11(1):10-7. Available from: https://periodicos.ufpe.br/revistas/revistaenfermagem/article/ view/11872/14321

16. Instituto de Pesquisa Econômica Aplicada-IPEA. Infraestrutura social e urbana no Brasil: subsídios para uma agenda de pesquisa e formulação de políticas públicas [Internet]. Brasília, DF: Ipea; 2010 [cited 2018 Apr 2]. Available from: http://www.ipea.gov.br/portal/images/ stories/PDFs/livros/livros/42543_Livro_InfraestruturaSocial_vol2.pdf

17. Vogel TR, Petroski GF, Kruse RL. Impact of amputation level and comorbidities on functional status of nursing home residents following lower extremity amputation. J Vasc Surg [Internet]. 2014 [cited 2018 Apr 2];59(5):1323-30. Available from: https://www.ncbi.nlm.nih.gov/ pmc/articles/PMC4004653/pdf/nihms-554687.pdf

18. Sanz MMF, León MM, García MJR, Santiago FJF, Cámara FJN. Profile of institutionalized elderly people in private residential homes in the city of Soria (Spain). Fisioter. 2012;34(6):239-44. doi: 10.1016/j.ft.2012.03.007

19. Frutos Bernal E, Martín Corral JC, Martín Corral J, Galindo Villardón P. Profile of the elderly institutionalised in private residences in the Abadengo area in Salamanca. Rev Esp Geriatr Gerontol. 2013;48(4):203-4. doi: 10.1016/j.regg.2013.03.003

20. Tavares DMS, Gávea Jr SA, Dias FA, Santos NMF, Oliveira PB. [Quality of life and functional capacity of elderly people residents in rural area]. Rev RENE [Internet]. 2011 [cited 2018 Apr 2];12:895-903. Available from: http://www.periodicos.ufc.br/rene/article/view/4458/3379 Portuguese.

21. Morais EP, Rodrigues RAP, Gerhardt TE. [The oldest elders in rural life: reality of life and health of a population of the gaúcho countryside]. Texto Contexto Enferm [Internet]. 2008 [cited 2018 Apr 2];17(2):374-83. Available from: http://www.scielo.br/pdf/tce/v17n2/21.pdf Portuguese.

22. Freitas MC, Queiroz TA, Sousa JAV. [The meaning of old age and the aging experience of in the elderly]. Rev Esc Enferm USP [Internet]. 2010 [cited 2018 Apr 2];44(2):407-12. Available from: http://www.scielo.br/pdf/reeusp/v44n2/24.pdf Portuguese.

23. Marchon RM, Cordeiro RC, Nakano MM. [Funtional capacity of elderly people living in a long-term care facility: a prospective study]. Rev Bras Geriatr Gerontol [Internet]. 2010 [cited 2018 Apr 2];13(2):203-14. Available from: http://www.scielo.br/pdf/rbgg/v13n2/a05v13n2.pdf Portuguese. 
24. Lisboa CR, Chianca TCM. [Epidemiological, clinical and of functional independence profile of an institutionalized elderly population]. Rev Bras Enferm [Internet]. 2012 [cited 2018 Apr 2];65(3):482-7. Available from: http://www.scielo.br/pdf/reben/v65n3/v65n3a13.pdf Portuguese.

25. Landi F, Calvani R, Picca A, Tosato M, Matone AM, D`Angelo E, et al. Impact of habitual physical activity and type of exercise on physical performace across ages in community-living people. PloS One [Internet]. 2018 [cited 2018 Apr 10];13(1):e0191820. Available from: http:// journals.plos.org/plosone/article?id=10.1371/journal.pone.0191820

26. Streit IA, Fortunato AR, Machado JC, Hauser E, Mazo GZ. [Physical activity level and habits in leisure elderly centenarians]. Rev Kairós Gerontol [Internet]. 2015 [cited 2018 Apr 10];18(4):165-77. Available from: http://angsc.org.br/arquivos/n-nfostzecta_ines_3.pdf Portuguese.

27. Verçosa VSL, Cavalcanti SL, Freitas DA. Prevalence of depressive symptomology in institutionalized elderly people. Rev Enferm UFPE[Internet]. 2016 [cited 2018 Apr 2];10(5):4264-70. Available from: https://periodicos.ufpe.br/revistas/revistaenfermagem/article/ view/11172/12707

28. Freire HSS, Oliveira AKS, Nascimento MRF, Conceição MS, Nascimento CEM, Araújo PF, et al. [Application of the Yesavage Geriatric Depression Scale in long-term institutions]. Nurs. 2018 [cited 2018 Apr 2];21(237):2030-5. Available from: http://www.revistanursing.com.br/ revistas/237-Fevereiro2018/aplicacao_da_escala_de_depressao_geriatrica.pdf Portuguese.

29. Rocha JP, Klein OJ, Pasqualotti A. [Quality of life, depression and cognition based on gerontological education mediated by a pole radio in homes for the aged]. Rev Bras Geriatr Gerontol [Internet]. 2014 [cited 2018 Apr 2];17(1):115-28. Available from: http://www.scielo.br/pdf/ rbgg/v17n1/1809-9823-rbgg-17-01-00115.pdf Portuguese.

30. Li IC, Kuo HT, Lin KC, Wu YC. The effects of depressive symptoms on quality of life among institutionalized older adults in Taiwan. Perspect Psychiatr Care. 2014;50(1):58-64. doi: 10.1111/ppc.12029

31. Lai CK, Leung DD, Kwong EW, Lee RL. Factors associated with the quality of life of nursing home residents in Hong Kong. Int Nurs Rev. 2015;62(1):120-9. doi: 10.1111/inr.12152 